\title{
PENGARUH DUKUNGAN SOSIAL DAN STRATEGI NAFKAH TERHADAP KESEJAHTERAAN SUBJEKTIF KELUARGA USIA PENSIUN
}

\author{
Sri Sulastri $\left.{ }^{*}\right)$, Hartoyo ${ }^{1}$ \\ ${ }^{1}$ Departemen IImu Keluarga dan Konsumen, Fakultas Ekologi Manusia, Institut Pertanian Bogor, \\ Bogor 16680, Indonesia \\ ${ }^{*}$ E-mail: srisulastri_ikk46@yahoo.com
}

\begin{abstract}
Abstrak
Usia pensiun seringkali identik dengan masa-masa penurunan kesejahteraan baik ekonomi, fisik, psikologis, dan sosial. Lingkungan yang mendukung dan alternatif sumber pendapatan yang tersedia akan menentukan kebahagiaan memasuki masa pensiun. Penelitian ini bertujuan untuk menganalisis pengaruh dukungan sosial dan strategi nafkah terhadap kesejahteraan subjektif keluarga usia pensiun. Desain yang digunakan dalam penelitian adalah cross sectional. Penelitian ini melibatkan 154 keluarga dengan suami dan atau istri berusia lebih atau sama dengan 56 tahun dan sudah pensiun. Penelitian dilakukan di Kota dan Kabupaten Bogor sebagai representasi wilayah perkotaan dan perdesaan. Contoh dipilih secara purposive sampling dengan riwayat pekerjaan dibedakan menjadi PNS dan bukan PNS. Data dikumpulkan melalui wawancara dengan alat bantu kuesioner kemudian dianalisis dengan uji beda independent sample t-test dan uji regresi linier berganda. Hasil penelitian ini menunjukkan kesejahteraan subjektif keluarga PNS lebih tinggi dibandingkan dengan bukan PNS. Faktor yang memengaruhi kesejahteraan subjektif keluarga usia pensiun adalah pendapatan keluarga, dukungan sosial, dan strategi nafkah.
\end{abstract}

Kata kunci: dukungan sosial, keluarga pensiun, subjektif, strategi nafkah

\section{Effect of Social Support and Livelihood Strategies on Subjective Well-Being of Family at Retirement Age}

\begin{abstract}
The retirement age is often refers with periods of decline of welfare including economic condition, physical, psychological, and social. A supported environment and availability of alternative source of income will determine the happines of retirement age. This aim of this study was to analyze the influence of social support and livelihood strategies on subjective well-being of family at retirement age. This study used cross sectional study design. This research involved 154 families with husband or wives aged 56 years old or above and being retired. The samples were selected purposively and grouped into two categories (government officer and nongovernment officer). Data were collected by interview used questionnaire and analyzed by compare means independent sample t-test and multiple linear regression. Results of this study indicated that subjective well-being of government officer families was higher than nongovernment officer. Factors that influenced subjective well-being of family at retirement age were family income, social support, and livelihood strategies.
\end{abstract}

Keyword: livelihood strategies, social support, subjective well-being

\section{PENDAHULUAN}

Peningkatan pelayanan kesehatan dan membaiknya keadaan ekonomi membawa dampak terhadap peningkatan usia harapan hidup sehingga semakin banyak orang yang akan mencapai usia lanjut (Oswari, 1985). Sebagai akibat dari usia harapan hidup yang semakin lama, jumlah penduduk usia di atas 60 tahun mengalami peningkatan. Hasil sensus penduduk tahun 2010 menunjukkan bahwa jumlah penduduk lansia di Indonesia adalah 18,57 juta jiwa, meningkat dibandingkan jumlah pada tahun 2000 yaitu 14,44 juta jiwa. Jumlah penduduk lansia di Indonesia diperkirakan akan terus bertambah sekitar 450.000 jiwa per tahun. Dengan demikian, pada tahun 2025 jumlah penduduk lansia di Indonesia diperkirakan berjumlah sekitar 34,22 juta jiwa (BPS, 2010).

Secara umum, usia lanjut dini dibatasi oleh rentang usia antara 60-70 tahun yang mana pada masa tersebut ditandai oleh berbagai perubahan baik secara fisik maupun mental (Hurlock, 1980). Saat memasuki usia lanjut, lansia dihadapkan pada berbagai tantangan baru seperti pensiun, kehilangan pasangan, 
tinggal jauh dari anak-anak maupun cucu, dan penurunan fungsi fisik. Hal tersebut merupakan stresor utama bagi lansia, yang menyebabkan lansia merasa tidak berguna dan tidak mampu berbuat apa-apa. Disfungsi yang dialami oleh lansia memungkinkan lansia akan merasa sedih, cemas, dan tidak berharga (Bozo, Toksabay, \& Kurum, 2009).

Selain hal perubahan fisik pada lansia, masa pensiun seringkali menjadi masalah utama bagi lansia karena pensiun merupakan akhir pola hidup atau masa transisi ke pola hidup yang baru. Pensiunan selalu menyangkut perubahan peran, perubahan keinginan dan nilai, dan perubahan secara keseluruhan terhadap pola hidup setiap individu (Schwartz, 1974). Masa pensiun tidak terlepas dari masa tua. Pendapat ini sejalan dengan pernyataan Havighurst (1961) bahwa salah satu tugastugas perkembangan pada masa tua adalah menyesuaikan diri dengan masa pensiun dan berkurangnya penghasilan sehingga individu yang telah memasuki masa pensiun harus dapat menyesuaikan diri pada masa pensiunnya dengan baik.

Apabila individu mampu menyelesaikan suatu tahap perkembangan dengan penyesuaian diri yang baik maka individu tersebut akan lebih mudah dalam menempuh tahap perkembangan selanjutnya. Begitu pula bila individu yang telah pensiun mampu menyelesaikan tugas perkembangannya pada masa pensiun maka individu tersebut mencapai kesuksesan atau usia yang optimal di hari tuanya. Beberapa penelitian menunjukkan bahwa kesuksesan yang dicapai pada usia lansia terdiri atas tiga dimensi yaitu fisik, mental, dan kesehatan sosial (Rowe \& Kahn, 1997). Penelitian Herawati, Krisnatuti, dan Alfiasari (2013) menemukan bahwa terdapat perbedaan kualitas perkembangan pada dimensi kognitif, reflektif, afektif, dan total kualitas perkembangan antara kakek dan nenek. Temuan tersebut menyebutkan bahwa kualitas perkembangan yang dimiliki oleh kakek lebih baik dibandingkan dengan kualitas perkembangan yang dimiliki oleh nenek.

Pada keluarga dengan usia lansia, sering kali keluarga inti tidak dapat membantu secara ekonomi maupun secara sosial (Prayitno, 1984). Padahal masalah yang paling serius dalam penyesuaian terhadap pensiun adalah yang berhubungan dengan anggota keluarga sehingga pada masa ini seseorang yang pensiun membutuhkan dukungan sosial. Menurut Smet (1994), dukungan sosial berperan untuk melindungi seorang dari dampak negatif yang diakibatkan oleh stres.
Diantara semua komponen kesuksesan hidup pada lansia, menurut Hsu (2010) diperlukan keamanan ekonomi. Semakin baik kondisi keuangan maka semakin besar kepuasan hidup (Gray, Ventis, \& Hayslip, 1992). Saat seseorang memasuki masa pensiun, salah satu perubahan yang dialami yaitu berkurangnya penghasilan yang didapat. Temuan sebelumnya menunjukkan bahwa stabilitas ekonomi sangat penting untuk kesejahteran pada masa tua (Hsu, 2010). Orang tua memiliki tiga sumber utama dukungan finansial yaitu individu, keluarga, dan masyarakat. Beberapa orang tua masih memiliki kesulitan keuangan yang serius dan tidak puas dengan standar hidup yang rendah pada tingkat dasar. Hal ini membutuhkan upaya yang lebih dari pemerintah untuk memperbaiki sistem pensiun perdesaan dan meningkatkan investasi keuangan untuk proyek-proyek kesejahteraan bagi mereka (Shen et al., 2011).

Selain dukungan sosial, strategi nafkah juga diperlukan dalam menghadapi perubahan kondisi keuangan yang terjadi di masa pensiun. Strategi nafkah merupakan cara manusia untuk memenuhi kebutuhan dan memperbaiki hidup (Chamber \& Conway, 1991). Berbagai aset yang ada akan menentukan cara strategi nafkah dibentuk dalam rangka meningkatkan kesejahteraan karena aset (capital) tersebut memberikan orang kemampuan (capability). Dengan menerapkan berbagai strategi nafkah (livelihood diversity) bertumpu pada sumber daya yang dimiliki setiap rumah tangga dapat meningkatkan derajat kesejahteraannya (Tulak, Dharmawan, \& Juanda, 2009). Berbeda dengan penelitian sebelumnya, penelitian ini ingin melihat strategi nafkah yang dilakukan oleh seseorang pada usia yang sudah tidak produktif.

Kesejahteraan merupakan aspek atau tujuan akhir yang diharapkan oleh semua orang. Chen, Shiho, dan Kiyoko (2010) mendefinisikan kesejahteraan subjektif merupakan kepuasan kehidupan secara keseluruhan. Kualitas hidup itu sendiri dipengaruhi oleh keadaan psikologis, mental, sosial, ekonomi, dan karakteristik pribadi seseorang (Osborne et al., 2003; Chen, Shiho, \& Kiyoko, 2010). Menurut Liu dan Guo (2008), status ekonomi dan masalah keuangan dapat menyebabkan pembatasan dalam kemampuan seseorang untuk mandiri dan memenuhi kebutuhan sehingga akan berdampak pada kesejahteraan. Oleh karenanya, penelitian ini bertujuan untuk menganalisis dukungan sosial dan strategi nafkah serta pengaruhnya terhadap kesejahteraan subjektif keluarga usia pensiun. 


\section{METODE}

Penelitian ini menggunakan desain cross sectional dan dilakukan di Kabupaten Bogor dan Kota Bogor, masing-masing diwakili dua kompleks perumahan. Pemilihan lokasi dilakukan secara purposive dengan pertimbangan terdapat banyak keluarga usia pensiun yang memiliki latar belakang pekerjaan yang sesuai dengan kriteria penelitian. Pengambilan data dilakukan selama dua bulan yaitu pada bulan April-Mei 2013.

Populasi penelitian ini adalah keluarga yang telah memasuki usia pensiun ( $\geq 56$ tahun) dan tinggal di wilayah Kota Bogor dan Kabupaten Bogor yaitu di empat perumahan yang telah ditentukan. Kerangka contoh dalam penelitian ini adalah pensiunan Pegawai Negeri Sipil (PNS) dan pegawai bukan PNS (termasuk didalamnya pegawai swasta, wiraswasta dan pegawai BUMN) dari berbagai tingkat ekonomi dengan usia di atas atau sama dengan 56 tahun dan tinggal di empat perumahan tersebut. Penarikan contoh dilakukan secara purposive sampling dengan jumlah contoh yang diambil 160 keluarga. Setelah dilakukan cleaning data didapatkan 154 keluarga. Responden dalam penelitian ini adalah suami atau istri yang telah memasuki usia pensiun yang ditemui pada saat pengambilan data.

\section{Penelitian ini menggunakan data primer yang dikumpulkan melalui wawancara kuesioner, yaitu karakteristik pensiunan, karakteristik keluarga, dukungan sosial, strategi nafkah, dan kesejahteraan subjektif. Karakteristik pensiunan terdiri atas jenis kelamin, usia, pendidikan, dan pekerjaan. Karakteristik keluarga terdiri atas lama pernikahan, jumlah tanggungan keluarga, dan pendapatan keluarga.}

Instrumen dukungan sosial diacu dan dimodifikasi dari Cutrona (1996). Dukungan sosial dalam penelitian ini diukur berdasarkan empat dimensi yaitu dukungan emosi, instrumental, informasi, dan self-esteem dengan jumlah pertanyaan sebanyak 30 . Instrumen strategi nafkah dikembangkan oleh peneliti dengan merujuk pada teori Scoones (1998) yang mengukur strategi nafkah dengan menggolongkan menjadi tiga golongan yaitu rekayasa sumber nafkah, pola nafkah ganda, dan rekayasa spasial (migrasi) dengan jumlah 15 pertanyaan. Instrumen kesejahteraan subjektif diacu dan dimodifikasi oleh peneliti dari Puspitawati (2009) yang mengukur kesejahteraan subjektif dengan empat dimensi yaitu ekonomi, fisik, psikologis, dan sosial dengan jumlah 22 penyataan. Instrumen kesejahteraan subjektif, khususnya pada dimensi ekonomi merujuk pada material living standards yang termasuk dalam key dimension of well being pada Commission on the Measurement of Economic Performance and Social Progress. Pernyataan mengenai material living standards mencakup pernyataan mengenai pendapatan, konsumsi dan kekayaan yang dirasakan.

Kuesioner dukungan sosial dan strategi nafkah diukur dengan menggunakan skala Likert dari 1-5 (sangat tidak setuju-sangat setuju). Kesejahteraan subjektif keluarga juga diukur dengan skala likert dari 1-5 (sangat tidak puas-sangat puas). Nilai Cronbach's alpha untuk instrumen dukungan sosial, strategi nafkah, dan kesejahteraan subjektif berturutturut sebesar 0,809, 0,845, dan 0,865.

Pengolahan data dukungan sosial dan kesejahteraan subjektif ditransformasikan dalam bentuk indeks 0 hingga 100 dan dikategorikan menjadi kurang (0-60), sedang (60-80), dan tinggi (80-100). Analisis data dalam penelitian ini meliputi analisis deskriptif dan inferensial. Analisis deskriptif meliputi frekuensi, rata-rata, standar deviasi, nilai minimum, dan nilai maksimum. Sementara itu, analisis inferensial yang dilakukan dalam penelitian ini yaitu uji beda independent sample $t$-test yang digunakan untuk melihat perbedaan karakteristik pensiunan, karakteristik keluarga, dukungan sosial, strategi nafkah, dan kesejahteraan subjektif berdasarkan riwayat pekerjan dan uji regresi linear berganda yang digunakan untuk menganalisis pengaruh karakteristik pensiunan, karakteristik keluarga, dukungan sosial, serta strategi nafkah terhadap kesejahteraan subjektif keluarga.

\section{HASIL}

\section{Karakteristik Pensiunan dan Keluarga}

Sebagian besar pensiunan baik PNS $(81,82 \%)$ maupun bukan PNS $(85,71 \%)$ berjenis kelamin laki-laki. Rata-rata usia pensiunan PNS adalah 61,5 tahun sedangkan bukan PNS 60,3 tahun. Berdasarkan lama pendidikan, rata-rata pensiunan PNS menempuh pendidikan selama 13,5 tahun sedangkan bukan PNS menempuh pendidikan selama 12,7 tahun. Rata-rata lama pernikahan pada pensiunan PNS adalah 33,9 tahun sedangkan bukan PNS 32,7 tahun. Rata-rata jumlah tanggungan keluarga pensiunan PNS 
dan bukan PNS sebanyak 3 orang. Berdasarkan pendapatan keluarga, pensiunan PNS rata-rata memperoleh pendapatan sebesar Rp5.117.262,3 ( \pm Rp2.532.680,1) sedangkan bukan PNS sebesar Rp4.666.235,9 ( \pm Rp2.992.357,8). Hasil uji beda pada Tabel 1 menunjukkan perbedaan yang signifikan dalam hal lama pendidikan antara pensiunan PNS dan bukan PNS $(p<0,05)$. Sementara karakteristik contoh dan keluarga lainnya tidak berbeda signifikan $(p>0,05)$.

\section{Dukungan Sosial}

Sebaran pensiunan berdasarkan dukungan sosial ditunjukkan pada Tabel 2. Hasil penelitian menunjukkan bahwa hampir satu pertiga pensiunan PNS (32,5\%) dan kurang dari satu per tiga bukan PNS $(23,4 \%)$ memiliki dukungan emosi terkategori tinggi. Artinya baik pensiunan PNS dan bukan PNS telah banyak menerima dukungan emosi seperti dicintai, diperhatikan, dan merasa tidak sendiri. Sementara itu, hasil lain menunjukkan bahwa hanya 5,2 persen pensiunan PNS dan 2,6 persen bukan PNS memiliki dukungan instrumental terkategori tinggi. Hasil tersebut menunjukkan bahwa baik pensiunan PNS dan bukan PNS masih sedikit yang mendapatkan dukungan instrumental baik berupa bantuan uang, tempat tinggal, atau berupa bantuan fisik lainnya.

Tabel 1 Nilai rata-rata, standar deviasi, dan koefisien uji beda karakteristik pensiunan dan keluarga

\begin{tabular}{lccc}
\hline & \multicolumn{2}{c}{$\begin{array}{c}\text { Rata-rata } \pm \text { Standar } \\
\text { deviasi }\end{array}$} & $\begin{array}{c}p- \\
\text { Variabel }\end{array}$ \\
\cline { 2 - 3 } & PNS & $\begin{array}{c}\text { Bukan } \\
\text { PNS }\end{array}$ & \\
\hline $\begin{array}{l}\text { Usia } \\
\text { pensiunan } \\
\text { (tahun) }\end{array}$ & $61,5 \pm 4,6$ & $60,3 \pm 4,7$ & 0,114 \\
$\begin{array}{l}\text { Lama } \\
\text { pendidikan } \\
\text { pensiunan } \\
\text { (tahun) }\end{array}$ & $13,5 \pm 2,3$ & $12,7 \pm 25$ & $0,045^{*}$ \\
$\begin{array}{l}\text { Lama } \\
\text { pernikahan } \\
\text { (tahun) }\end{array}$ & $33,9 \pm 8,6$ & $32,7 \pm 6,8$ & 0,334 \\
$\begin{array}{l}\text { Jumlah } \\
\text { tanggungan } \\
\text { keluarga } \\
\text { (orang) }\end{array}$ & $3,0 \pm 1,1$ & $3,0 \pm 1,3$ & 0,121 \\
\hline $\begin{array}{l}\text { Keterangan: } \\
\text { *Signifikan pada } p<0,05, \\
\text { **Signifikan pada } p<0,001\end{array}$ & & \\
\hline
\end{tabular}

Selanjutnya, hanya sebesar 2,6 persen pensiunan PNS dan sebesar 5,2 persen bukan PNS memiliki dukungan informasi terkategori tinggi. Hasil tersebut menunjukkan bahwa baik pensiunan PNS dan bukan PNS masih sedikit yang mendapatkan dukungan informasi dalam bentuk informasi yang diberikan baik itu melalui saran, petunjuk, atau berupa nasehat sehingga pensiunan merasa terbantu mengatasi permasalahan yang dihadapi. Hasil penelitian menemukan bahwa lebih dari satu per tiga pensiunan PNS $(39,0 \%)$ dan kurang dari satu per tiga bukan PNS (28,6\%) memiliki dukungan self-esteem terkategori tinggi. Hasil uji beda menunjukkan tidak terdapat perbedaan yang signifikan antara pensiunan PNS dan pensiunan bukan PNS pada dukungan emosi, dukungan instrumental, dukungan informasi, dan dukungan self-esteem $(p>0,05)$.

Apabila dikompositkan untuk seluruh dimensi dukungan sosial, hasil penelitian ini menunjukkan hanya 5,2 persen pensiunan PNS dan 6,5 persen bukan PNS yang memiliki dukungan sosial terkategori tinggi. Sebaliknya, terdapat sekitar tiga dari sepuluh pada kelompok PNS $(33,8 \%)$ dan empat dari sepuluh pada kelompok bukan PNS $(39,6 \%)$ yang justru masih rendah dukungan sosialnya. Hasil uji beda menunjukkan tidak terdapat perbedaan yang signifikan antara pensiunan PNS dan pensiunan bukan PNS pada dukungan sosial total $(p>0,05)$. Sebaran pensiunan baik pensiunan PNS maupun pensiunan bukan PNS berdasarkan dimensi dukungan sosial disajikan pada Tabel 2.

Tabel 2 Sebaran pensiunan PNS dan pensionan bukan PNS berdasarkan dimensi dukungan sosial (\%)

\begin{tabular}{|c|c|c|c|c|}
\hline $\begin{array}{c}\text { Dukungan } \\
\text { sosial }\end{array}$ & $\mathrm{R}$ & $\mathrm{S}$ & $\mathrm{T}$ & Total \\
\hline \multicolumn{5}{|c|}{ Dukungan emosi } \\
\hline PNS & 26,0 & 41,5 & 32,5 & 100,0 \\
\hline Bukan PNS & 23,4 & 53,2 & 23,4 & 100,0 \\
\hline \multicolumn{5}{|c|}{ Dukungan instrumental } \\
\hline PNS & 75,3 & 19,5 & 5,2 & 100,0 \\
\hline Bukan PNS & 71,4 & 26,0 & 2,6 & 100,0 \\
\hline \multicolumn{5}{|c|}{ Dukungan informasi } \\
\hline PNS & 67,5 & 29,9 & 2,6 & 100,0 \\
\hline Bukan PNS & 62,3 & 32,5 & 5,2 & 100,0 \\
\hline \multicolumn{5}{|c|}{ Dukungan self-esteem } \\
\hline PNS & 15,6 & 45,4 & 39,0 & 100,0 \\
\hline Bukan PNS & 15,6 & 55,8 & 28,6 & 100,0 \\
\hline
\end{tabular}

Keterangan:

$\mathrm{R}=$ Dukungan sosial rendah,

$\mathrm{S}=$ Dukungan sosial sedang,

$\mathrm{T}=$ Dukungan sosial tinggi 
Tabel 3 Proporsi pensiunan dalam melakukan strategi nafkah

\begin{tabular}{lrr}
\hline \multicolumn{1}{c}{ Strategi nafkah } & $\begin{array}{c}\text { Pensiunan } \\
\text { PNS }\end{array}$ & $\begin{array}{c}\text { Pensiunan } \\
\text { Bukan PNS }\end{array}$ \\
\hline Rekayasa sumber & & \\
nafkah & 71,4 & 71,4 \\
Pola nafkah ganda & 38,9 & 35,1 \\
Rekayasa spasial & 12,9 & 10,4 \\
\hline
\end{tabular}

\section{Strategi Nafkah}

Scoones (1998) menggolongkan strategi nafkah menjadi tiga golongan, yaitu rekayasa sumber nafkah, pola nafkah ganda, dan rekayasa spasial (migrasi). Berdasarkan Tabel 3 , hampir tiga per empat keluarga pensiunan PNS $(71,43 \%)$ dan bukan PNS (71,43\%) menggunakan rekayasa sumber nafkah dalam melakukan strategi nafkah. Rekayasa sumber nafkah yang banyak dilakukan yaitu memanfaatkan pendapatan yang dimiliki secara maksimal.

Sementara itu, lebih dari satu per tiga keluarga pensiunan PNS (38,9\%) dan bukan PNS $(35,1 \%)$ menggunakan pola nafkah ganda dalam melakukan strategi nafkah (Tabel 3). Pola nafkah ganda yang banyak dilakukan yaitu melibatkan anggota keluarga (istri atau suami dan anak) untuk bekerja meskipun pensiunan sudah memiliki penghasilan tetap. Hal tersebut dilakukan untuk menambah pendapatan keluarga. Keterlibatan seluruh anggota keluarga dalam mencari nafkah merupakan suatu strategi nafkah sebagai upaya untuk bertahan hidup sekaligus respon keluarga terhadap kondisi kehidupan (Zid, 2011).

Begitu pun dengan rekayasa spasial (migrasi) dalam melakukan strategi nafkah lebih banyak dilakukan oleh keluarga pensiunan PNS $(12,9 \%)$ dibandingkan dengan bukan PNS $(10,4 \%)$ seperti yang tersaji pada Tabel 3 . Rekayasa spasial (migrasi) yang dilakukan adalah adanya anggota keluarga yang bekerja di luar daerah tempat tinggal untuk memperoleh pendapatan yang lebih besar. Hasil uji beda juga menunjukkan tidak terdapat perbedaan yang signifikan pada stategi nafkah antara pensiunan PNS dan pensiunan bukan PNS.

\section{Kesejahteraan Subjektif}

Kesejahteraan subjektif berdasarkan pendekatan Quality of Life adalah mengukur kepuasan atau kesenangan seseorang secara subjektif terhadap semua materi dan perilaku yang dilakukan untuk mencapai tujuan hidup (Puspitawati, 2009). Ukuran kepuasan ini dapat berbeda-beda untuk setiap individu atau bersifat subjektif. Puas atau tidaknya seseorang dapat dihubungkan dengan nilai yang dianut oleh orang tersebut dan tujuan yang diinginkan. Sebaran keluarga pensiunan berdasarkan kesejahteraan subjektif ditunjukkan pada Tabel 4 . Kesejahteraan subjektif keluarga dalam penelitian ini dilihat dari empat dimensi yaitu ekonomi, fisik, psikologis, dan sosial. Kesejahteraan subjektif dimensi ekonomi terdiri atas kepuasan pensiunan terhadap pendapatan, konsumsi, dan kekayaan yang dirasakan. Hasil penelitian ini menunjukkan bahwa hanya 11,7 pensiunan PNS dan 9,1 persen bukan PNS memiliki kesejahteraan ekonomi terkategori tinggi (Tabel 4). Hasil tersebut menunjukkan bahwa masih sedikit pensiunan yang merasa sangat puas dengan keadaan ekonomi setelah pensiun.

Sementara itu, kesejahteraan keluarga secara fisik terdiri atas keadaan kesehatan pensiunan dan keluarga. Hasil penelitian ini menemukan bahwa hanya 5,2 persen pensiunan PNS dan 3,9 persen bukan PNS memiliki kesejahteraan fisik terkategori rendah (Tabel 4). Hal tersebut menunjukkan bahwa lebih sedikit pensiunan yang merasa tidak puas dengan keadaan fisik setelah pensiun. Pensiunan telah puas dengan keadaan rumah, pakaian, dan kesehatan setelah pensiun. Selanjutnya, kesejahteraan keluarga secara psikologis terdiri atas keadaan mental dan spiritual pensiunan dan keluarga. Hasil penelitian menunjukkan bahwa hanya 3,9 persen pensiunan PNS dan 9,1 persen bukan PNS memiliki kesejahteraan psikologis terkategori rendah yang berarti lebih sedikit pensiunan yang merasa tidak puas dengan keadaan psikologis setelah pensiun (Tabel 4).

Tabel 4 Sebaran pensiunan PNS dan bukan PNS berdasarkan kesejahteraan dimensi subjektif dimensi ekonomi, fisik, psikologis, dan sosial (\%)

\begin{tabular}{|c|c|c|c|c|}
\hline $\begin{array}{l}\text { Kesejahteraan } \\
\text { subjektif }\end{array}$ & $\mathrm{R}$ & S & $\mathrm{T}$ & Total \\
\hline \multicolumn{5}{|c|}{ Kesejahteraan ekonomi } \\
\hline PNS & 36,4 & 51,9 & 11,7 & 100,0 \\
\hline Bukan PNS & 48,0 & 42,9 & 9,1 & 100,0 \\
\hline \multicolumn{5}{|c|}{ Kesejahteraan fisik } \\
\hline PNS & 5,2 & 36,4 & 58,4 & 100,0 \\
\hline Bukan PNS & 3,9 & 44,2 & 51,9 & 100,0 \\
\hline \multicolumn{5}{|c|}{ Kesejateraan psikologis } \\
\hline PNS & 3,9 & 35,1 & 61,0 & 100,0 \\
\hline Bukan PNS & 9,1 & 49,3 & 41,6 & 100,0 \\
\hline \multicolumn{5}{|c|}{ Kesejahteraan sosial } \\
\hline PNS & 3,9 & 20,8 & 75,3 & 100,0 \\
\hline Bukan PNS & 6,4 & 48,0 & 48,0 & 100,0 \\
\hline
\end{tabular}


Hasil lainnya, kesejahteraan keluarga secara sosial mencakup hubungan komunikasi antarsesama anggota keluarga serta komunikasi dengan keluarga besar dan lingkungan di luar keluarga. Penelitian ini menemukan bahwa hanya 3,9 persen pensiunan PNS dan 6,4 persen bukan PNS yang memiliki kesejahteraan sosial terkategori rendah. Temuan ini menegaskan bahwa lebih sedikit pensiunan yang merasa tidak puas dengan keadaan sosial setelah pensiun. Para pensiunan telah merasa puas dengan hubungan dengan pasangan, anggota keluarga, dan lingkungan disekitarnya setelah pensiun. Hasil uji beda menunjukkan terdapat perbedaan yang signifikan antara pensiunan PNS dan bukan PNS pada kesejahteraan sosial dan psikologis $(p<0,05)$.

Secara keseluruhan, hasil penelitian menunjukkan bahwa lebih dari separuh pensiunan PNS $(57,1 \%)$ dan lebih dari satu pertiga bukan PNS (39,0\%) memiliki kesejahteraan subjektif terkategori tinggi yang berarti pensiunan merasa sangat puas dengan keadaan ekonomi, fisik, psikologis, dan sosial setelah pensiun. Hasil uji beda juga menunjukkan terdapat perbedaan yang signifikan pada kesejahteraan subjektif antara contoh PNS dan bukan PNS $(p<0,05)$.

Pengaruh Karakteristik Pensiunan dan Keluarga, Dukungan Sosial, dan Strategi Nafkah terhadap Kesejahteraan Subjektif Keluarga Usia Pensiun

Kesejahteraan subjektif keluarga dapat dipengaruhi oleh berbagai faktor. Uji regresi linear berganda digunakan untuk mengetahui faktor-faktor yang memengaruhi kesejahteraan subjektif keluarga. Variabel yang menjadi variabel bebas dalam model regresi linear berganda yang digunakan adalah usia (tahun), lama pendidikan (tahun), lama pernikahan (tahun), jumlah tanggungan keluarga (orang), pendapatan keluarga (Rp/bulan), dukungan sosial, dan strategi nafkah.

Hasil uji regresi menunjukkan bahwa model yang dihasilkan memiliki nilai Adjusted $R$ Square sebesar 0,297, yang berarti bahwa 29,7 persen kesejahteraan subjektif keluarga dapat dijelaskan oleh variabel yang ada dalam model, sedangkan 70,3 persen sisanya dijelaskan oleh variabel yang tidak diteliti.

Hasil uji regresi linier berganda pada Tabel 5 menunjukkan bahwa faktor-faktor yang berpengaruh secara signifikan terhadap

kesejahteraan subjektif keluarga adalah pendapatan keluarga $(B=5,756 \mathrm{E}-7 ; \quad p<0,1)$, dukungan sosial $(B=0,302 ; \quad p<0,01)$, dan strategi nafkah $(B=-0,470 ; p<0,01)$. Pendapatan keluarga dan dukungan sosial memiliki pengaruh positif signifikan, sementara strategi nafkah berpengaruh negatif signifikan terhadap kesejahteraan subjektif.

Hasil tersebut menunjukkan bahwa setiap penambahan seratus ribu rupiah pendapatan keluarga per tahun akan menaikkan kesejahteraan subjektif sebesar 0,05756 poin dan peningkatan satu dukungan sosial akan menaikkan kesejahteran subjektif sebesar 0,302 poin. Selain itu, setiap penambahan satu strategi nafkah akan menurunkan kesejahteraan subjektif sebesar 0,470 poin.

Tabel 5 Koefisien regresi untuk analisis pengaruh karakteristik pensiunan, karakteristik keluarga, dukungan sosial, dan strategi nafkah terhadap kesejahteraan subjektif keluarga usia pensiun

\begin{tabular}{|c|c|c|c|}
\hline \multirow{2}{*}{$\begin{array}{c}\text { Variabel } \\
\text { bebas }\end{array}$} & \multicolumn{2}{|c|}{ Koefesien regresi } & \multirow{2}{*}{ Sig. } \\
\hline & (B) & $(\beta)$ & \\
\hline Konstanta & 80,871 & & 0,000 \\
\hline Usia (tahun) & $-0,255$ & $-0,101$ & 0,269 \\
\hline $\begin{array}{l}\text { Lama } \\
\text { pendidikan } \\
\text { pensiunan } \\
\text { (tahun) }\end{array}$ & 0,450 & 0,092 & 0,232 \\
\hline $\begin{array}{l}\text { Lama } \\
\text { pernikahan } \\
\text { (tahun) }\end{array}$ & 0,120 & 0,079 & 0,381 \\
\hline $\begin{array}{l}\text { Jumlah } \\
\text { tanggungan } \\
\text { keluarga } \\
\text { (orang) }\end{array}$ & $-0,228$ & $-0,023$ & 0,762 \\
\hline $\begin{array}{l}\text { Pendapatan } \\
\text { keluarga } \\
\text { (Rp/bulan) }\end{array}$ & $5,756 \mathrm{E}-7$ & 0,135 & $0,093^{*}$ \\
\hline $\begin{array}{l}\text { Kelompok } \\
(0=\text { nonPNS; } \\
1=\text { PNS })\end{array}$ & 2,252 & 0,096 & 0,190 \\
\hline $\begin{array}{l}\text { Dukungan } \\
\text { sosial } \\
\text { (indeks) }\end{array}$ & 0,302 & 0,296 & $0,000^{* * *}$ \\
\hline $\begin{array}{l}\text { Strategi } \\
\text { nafkah } \\
\text { (jumlah } \\
\text { strategi yang } \\
\text { dilakukan) }\end{array}$ & $-0,470$ & $-0,456$ & $0,000^{* * *}$ \\
\hline $\mathrm{F}$ & & & 7,656 \\
\hline Sig. & & & $0,000^{* * *}$ \\
\hline $\mathrm{R}^{2}$ & & & 7,656 \\
\hline Adjusted $\mathrm{R}^{2}$ & & & 0,297 \\
\hline
\end{tabular}




\section{PEMBAHASAN}

Dukungan sosial pada masa pensiun sangat dibutuhkan karena banyak perubahan kebiasaan yang harus dilakukan. Perubahan tersebut dapat menimbulkan stres sehingga dukungan sosial dapat digunakan sebagai pelindung (buffering effect) terhadap efek negatif dari stress. Dukungan sosial memegang peranan penting dalam memelihara keadaan psikologis individu yang mengalami tekanan (Smet, 1994). Hasil penelitian menunjukkan proporsi terbesar pensiunan PNS dan bukan PNS memiliki dukungan self-esteem yang berada pada kategori tinggi. Dukungan tersebut sangat penting diciptakan guna membangkitkan kembali semangat serta rasa percaya dirinya dalam menghadapi realitas kehidupan yang sedang dialami. Seseorang yang tengah menghadapi masa pensiun membutuhkan orang lain yang dapat membuatnya merasa dicintai, diperhatikan, serta tidak merasa sendirian dalam menghadapi masa usia senja tersebut (Kadarisman, 2011).

Hasil penelitian mengenai strategi nafkah menunjukkan bahwa baik pensiunan PNS maupun bukan PNS melakukan lebih dari satu strategi. Pensiunan PNS maupun bukan PNS lebih banyak melakukan strategi rekayasa sumber nafkah dibandingkan strategi lainnya. Strategi yang paling banyak dilakukan pada golongan rekayasa sumber nafkah adalah memanfaatkan pendapatan yang dimiliki secara maksimal. Kemampuan seseorang dalam mengombinasi sumber pendapatan dapat meningkatkan keamanan dalam melakukan strategi nafkah dan kemampuan untuk meningkatkan pendapatan rumah tangga (Ellis, 1998).

Strategi kedua yang banyak dilakukan oleh pensiunan PNS dan bukan PNS adalah pola nafkah ganda. Alasan utama melakukan strategi nafkah ganda pada rumah tangga berbeda-beda pada masing-masing lapisan. Pada rumah tangga lapisan atas, pola nafkah ganda merupakan strategi akumulasi modal dan lebih bersifat ekspansi usaha. Sementara itu, pada lapisan menengah, pola nafkah ganda merupakan upaya konsolidasi untuk mengembangkan ekonomi rumah tangga. Sebaliknya pada lapisan bawah, pola nafkah ganda merupakan strategi bertahan hidup pada tingkat subsistensi dan sebagai upaya untuk keluar dari kemiskinan (Sajogyo, 1982). Penerapan strategi nafkah, pensiunan PNS maupun bukan PNS dalam penelitian ini melakukan strategi nafkah ganda untuk mempertahankan kondisi ekonomi rumah tangga sehingga fungsi keluarga tetap bisa berjalan.

Kesejahteraan subjektif keluarga usia pensiun merupakan output dari proses pengelolaan sumber daya keluarga dan penanggulangan masalah yang dihadapi, termasuk didalamnya adalah pengambilan keputusan dalam penggunaan sumber daya yang dimiliki oleh keluarga. Kesejahteraan subjektif keluarga pensiunan PNS terkategori tinggi yang artinya keluarga telah merasa sangat puas terhadap semua kesejahteraan ekonomi, fisik, sosial, dan psikologi. Sementara itu, pensiunan bukan PNS rata-rata memiliki kesejahteraan subjektif terkategori sedang. Artinya, keluarga pensiunan yang bukan PNS merasa cukup puas terhadap semua aspek kesejahteraan subjektif, baik ekonomi, fisik, sosial, maupun psikologi.

Kesejahteraan subjektif menggambarkan penilaian seseorang terhadap kehidupannya yang mencakup indikator kesejahteraan fisik, sosial, dan psikologis (Puspitawati, Simanjuntak, \& Hayati, 2012). Hasil penelitian menunjukkan bahwa kesejahteraan subjektif keluarga pensiunan PNS lebih tinggi dibandingkan bukan PNS. Hasil tersebut dapat terjadi karena pendidikan dan pendapatan yang dimiliki pensiunan PNS lebih tinggi dibandingkan bukan PNS. Hal tersebut didukung dengan hasil uji beda yang menunjukkan perbedaan yang signifikan $(p<0,05)$ antara pensiunan PNS dan bukan PNS pada lama pendidikan yang mana ratarata lama pendidikan pensiunan PNS pada penelitian ini lebih tinggi.

Hasil penelitian sebelumnya menunjukkan bahwa pendidikan dan status keuangan merupakan faktor yang memengaruhi kesejahteraan (Chen, Shiho, \& Kiyoko 2010). Hal lain yang juga dapat menjelaskan kesejahteraan subjektif keluarga PNS lebih tinggi adalah PNS telah mengikuti dana pensiun wajib dari pemerintah atau perusahaan dari tempatnya bekerja. Tabungan pensiun yang dimiliki membuat pensiunan PNS merasa lebih aman karena sudah memiliki jaminan. Keamanan yang dirasakan pensiunan PNS dalam hal keuangan juga berdampak pada kesejahteraan yang dirasakan semakin meningkat.

Hasil uji pengaruh pada penelitian ini menemukan bahwa kesejahteraan subjektif secara signifikan dipengaruhi oleh pendapatan keluarga, dukungan sosial, dan strategi nafkah. Pendapatan keluarga berpengaruh positif signifikan terhadap kesejahteraan subjektif. 
Hasil penelitian tersebut didukung oleh hasil penelitian yang dilakukan Puspitasari, Puspitawati, \& Herawati (2013) yang menyatakan bahwa pendapatan keluarga berpengaruh terhadap kesejahteraan subjektif. Besarnya pendapatan akan meningkatkan peluang keluarga untuk mencapai kesejahteraan (Hartoyo \& Aniri, 2010). Pendapatan yang diterima keluarga setelah pensiun menentukan keadaan kesehatan keuangan keluarga. $\mathrm{Pe}$ nelitian secara konsisten menunjukkan pentingnya kesehatan keuangan yang memadai untuk kesejahteraan di masa pensiun (Van Solinge \& Henkens, 2008; Wang, 2007). Semakin baik keuangan ketika pensiun maka semakin baik pula kesejahteraan psikologisnya (Van \& Henkens, 2005). Dukungan sosial berpengaruh positif signifikan terhadap kesejahteraan subjektif. Hasil penelitian ini sesuai dengan penelitian yang dilakukan Muladsih, Muflikhati, dan Herawati (2011) bahwa adanya dukungan dari keluarga inti dapat meningkatkan motivasi individu untuk melakukan perencanaan dalam hidupnya sehingga tercapai kesejahteraan.

Faktor lain yang memengaruhi kesejahteraan subjektif adalah strategi nafkah. Hasil penelitian menunjukkan bahwa strategi nafkah berpengaruh negatif signifikan terhadap kesejahteraan subjektif. Artinya peningkatan jumlah strategi nafkah yang dilakukan pensiunan akan menurunkan kesejahteraan subjektif keluarga. Hasil penelitian menunjukkan bahwa pendapatan keluarga pensiunan sudah tergolong menengah atas dan keluarga sudah dapat memenuhi kebutuhan hidupnya. Kondisi tersebut menyebabkan keluarga pensiunan sudah menunjukkan perasaan kepuasan atau rasa syukurnya akan kehidupan keluarga, baik materi dan nonmateri yang diperolehnya saat ini. Banyaknya strategi nafkah yang dilakukan tergantung pada pendapatan yang dimiliki. Hal ini selaras dengan pernyataan Widodo (2011) bahwa indeks keragaman sumber pendapatan semakin menurun dengan meningkatnya pendapatan. Dengan pendapatan yang rendah maka strategi nafkah yang akan dilakukan pun semakin beragam. Kondisi inilah yang dapat menyebabkan kesejahteraan subjektif dapat menurun.

Hasil uji regresi tidak menemukan adanya pengaruh riwayat pekerjaan (PNS dan bukan PNS) terhadap kesejahteraan subjektif. Hasil penelitian ini menegaskan betapa pentingnya dukungan sosial bagi para pensiunan sehingga mereka mampu merasakah kehidupan yang lebih memuaskan di masa pensiun. Selain itu, jaminan ekonomi di masa pensiun juga menjadi faktor penting sehingga pensiunan yang memasuki masa lansia tidak perlu melakukan beragam strategi nafkah sehingga lebih dapat merasakan kepuasan hidup yang dijalaninya.

\section{SIMPULAN DAN SARAN}

Penelitian ini menemukan dukungan sosial yang diterima keluarga usia pensiun baik dengan riwayat pekerjaan PNS maupun bukan PNS terkategori sedang. Dukungan sosial yang paling banyak dimiliki keluarga usia pensiun terdapat pada dimensi self-esteem. Strategi rekayasa sumber nafkah merupakan strategi yang paling banyak dilakukan oleh keluarga usia pensiun setelah pensiun dibandingkan dengan strategi lainnya. Kesejahteraan subjektif keluarga PNS terkategori tinggi sedangkan kesejahteraan subjektif keluarga bukan PNS terkategori sedang.

Berdasarkan uji beda yang dilakukan, terdapat perbedaan signifikan pada lama pendidikan, kesejahteraan psikologis, kesejahteraan sosial, dan kesejahteraan subjektif total antara keluarga PNS dan bukan PNS. Keluarga PNS lebih lama menempuh pendidikan dibandingkan keluarga bukan PNS. Begitupun dengan kesejahteraan subjektif keluarga PNS lebih tinggi dibandingkan bukan PNS. Faktorfaktor yang memengaruhi ke-sejahteraan subjektif keluarga usia pensiun adalah pendapatan keluarga, dukungan sosial, dan strategi nafkah. Pendapatan keluarga dan dukungan sosial berpengaruh positif sedangkan strategi nafkah berpengaruh negatif terhadap kesejahteraan subjektif keluarga usia pensiun.

Berdasarkan hasil penelitian, diharapkan kepada berbagai pihak khususnya keluarga yang memiliki anggota keluarga yang sudah pensiun agar dapat memberikan dukungan sosial yang lebih baik agar kesejahteraan subjektif yang dirasakan pensiunan meningkat khususnya pada dukungan instrumental dan dukungan informasi karena dukungan tersebut masih kurang didapatkan oleh keluarga usia pensiun baik PNS maupun bukan PNS. Dalam aspek kesejahteraan subjektif, upaya yang dapat dilakukan untuk meningkatkan kesejahteraan keluarga, adalah minimal terdapat satu orang anggota keluarga yang bekerja dan dapat memenuhi kebutuhan dasar keluarga. Hasil lain yang ditemukan saat penelitian adalah masih terdapat pensiunan yang tidak mendapatkan gaji pensiunan per bulan. Menurut hasil temuan tersebut, perlu adanya pelatihan mengenai keterampilan dalam berwirausaha untuk para pegawai sebelum pensiun khususnya pegawai bukan PNS karena tidak semua pegawai bukan PNS 
ketika pensiun mendapatkan gaji pensiunan. Hal tersebut dilakukan agar pensiunan tidak tergantung kepada orang lain.

\section{DAFTAR PUSTAKA}

Bozo, Toksabay, N. E., \& Kurum, O. (2009). Activities of daily living depression and social support among elderly Turkish people. Journal pf Psycology, 143(2), 193205.

[BPS] Badan Pusat Statistik. (2010). Penduduk lanjut usia Indonesia 2010. Diambil dari http://bps.go.id. [diunduh 3 Jun 2013].

Chamber, R., \& Conway, G. (1991). Sustainable rural livehood: Concept practicals for $21^{\text {st }}$ century. IDS Discussion Paper, 296. IDS. Institute for Development Studies, Brighton.

Chen, J., Shiho, M., \& Kiyoko, K. (2010). Factors related to well being among the elderly in urban China focusing on multiple roles. Bioscience Trends, 4(2), 61-71.

Cutrona. (1996). Social support in couples. California, US: Sage Publications Inc.

Ellis, F. (1998) Household Strategies and rural livelihood diversification. The Journal of Development Studies, 35(1).

Gray, G. R., Ventis D. G., \& Hayslip B., Jr. (1992). Socio-cognitive skills as a determinant of life satisfaction in aged persons. International Journal of Aging and Human Development, 35(3), 205-218.

Hartoyo, \& Aniri, N. B. (2010). Analisis tingkat kesejahteraan keluarga pembudidaya ikan dan nonpembudidaya ikan di Kabupaten Bogor. Jur. IIm. Kel. \& Kons., 3(1), 64-73.

Havighurst R. J. (1961). Succesful aging. Gerontologist, 1, 8-13.

Herawati, P., Krisnatuti, D., \& Alfiasari. (2013). Interaksi dengan cucu, kualitas perkembangan, dan gejala stress pada kakek/nenek. Jur. IIm. Kel. \& Kons., 6(2), 1-9.

Hsu, H. C. (2010). Trajectory of life satisfaction and its relationship with subjective economic status and successful aging. Social Indicators Research, 99, 455-468.

Hurlock, E. B. (1980). Psikologi perkembangan suatu pendekatan sepanjang rentang kehidupan edisi kelima terjemahan Soegjarwo \& Istiwidayanti, penerjemah. Jakarta, ID: Penerbit Erlangga.
Kadarisman, M. (2011). Menghadapi pensiun dan kesejahteraan psikologis pegawai negeri sipil. Jurnal Kebijakan dan Manajemen PNS, 5(2).

Liu, L., \& Guo, Q. (2008). Life satisfaction in a sample of empty-nest elderly: A survey in the rural area of a mountainous county in China. Quality Life Research, 17, 823-830.

Muladsih, O. R., Muflikhati, I., \& Herawati, T. (2011). Pola komunikasi, pengambilan keputusan, dan kesejahteraan keluarga jarak jauh: Kasus keluarga mahasiswa pascasarjana. Jur. Ilm. Kel. \& Kons., 4(2), 121-129.

Osborne, R. H., Hawthorne, G., Lew, E. A., \& Gray, L. C. (2003). Quality of life assessment in the community-dwelling elderly: Validation of the Assessment of Quality of Life (AQoL) instrument and comparison with the SF-36. Journal of Clinical Epidemiology, 56(2), 138-147.

Oswari. (1985). Menyongsong hari tua: pegangan bagi siapa saja yang ingin menikmati senja kehidupan. Jakarta, ID: Gunung Mulia.

Prayitno. 1984. Manusia usia lanjut. Jakarta, ID: Inti Idayu Press.

Puspitasari, N., Puspitawati, H., \& Herawti, T. (2013). Peran gender, kontribusi ekonomi perempuan, dan kesejahteraan keluarga petani holtikultura. Jur. IIm. Kel. \& Kons., 6(1), 10-19.

Puspitawati, H. (2009). Pengaruh Nilai Ekonomi Pekerjaan lbu Rumah Tangga terhadap Kesejahteraan Keluarga Subjektif. Jur. IIm. Kel. \& Kons., 2(1), 11-20.

Puspitawati, H, Simanjuntak, M., \& Hayati, L. (2012). Kontribusi ekonomi dan peran ganda perempuan serta pengaruhnya terhadap kesejahteraan subjektif. Jur. IIm. Kel. \& Kons., 5(1), 11-16

Rowe, J. W., \& Kahn, R. L. (1997). The structure of successful aging. In J. W. Rowe \& R. L. Kahn (Eds.), Successful aging (pp. 36-52). New York, US: Dell.

Sajogyo. (1982). Modernization without development. The Journal of Social Studie.

Schwartz, A. N. (1974). Retirement: Termination or transition. Geriatrics, 29(5), 190-192, 195-198

Scoones, I. (1998). Sustainable rural livelihood: A Framework for Analysis. IDS Discussion Paper, 72. Institute for Development Studies, Brighton. 
Shen, S., Fang, Li., \& John, K. T. (2011). Quality of life and old age social welfare system for the rural elderly in China. Ageing Int, 37, 285-299.

Smet, B. (1994). Psikologi kesehatan. Jakarta, ID: PT. Grasindo.

Tulak, P. P., Dharmawan, A. H., \&Juanda, B. (2009). Struktur nafkah rumah tangga petani transmigran: Studi sosio-ekonomi di tiga kampong di Distrik Masni Kabupaten Manokwari. Sodality: Jurnal Trandisiplin Sosiologi, Komunikasi, dan Ekologi Manusia, 3(2), 203-220.

Widodo, S. (2011). Strategi nafkah berkelanjutan bagi rumah tangga miskin di daerah pesisir. Makara, Sosial Humaniora, 15(1).

Van, S. H., \& Henkens, K. (2005). Couple's adjustment to retirement: $A$ multi- actor panel study. The Journals of Gerontology Series B. Psychological Sciences and Social Sciences, 60(1), 11-20.

(2008). Adjustment to and satisfaction with retirement: Two of a kind?. Psychology and Aging, 23, 422434.

Wang, M. (2007). Profiling retirees in the retirement transition and adjustment process: Examining the longitudinal change patterns of retirees psychological well-being. Journal of Applied Psychology, 92, 455-474.

Zid, M. (2011). Fenomena strategi nafkah keluarga nelayan: Adaptasi ekologis di Cikahuripan-Cisolok, Sukabumi. Jurnal Sosialita, 9(1). 